\title{
NEUBROJIVI POČINITELJI PROTUPRAVNIH DJELA U KAZNENOM PRAVU I SUDSKOJ PRAKSI REPUBLIKE HRVATSKE ${ }^{1}$
}

\section{Sažetak}

U radu je prikazana zakonska regulativa položaja neubrojivih počinitelja protupravnih djela s aspekata kaznenog materijalnog i postupovnog prava te odredaba Zakona o zaštiti osoba s duševnim smetnjama kao i njihova primjena u praksi kroz analizu 25 pravomoćnih kaznenih presuda prema neubrojivim osobama, sve s ciljem uočavanja dobre sudske prakse, ali i pogrešnih postupanja sudova te neujednačenosti u postupanju, a radi podizanja kvalitete presuda otklanjanjem postupanja koja nisu u skladu sa zakonima i ujednačavanja sudske prakse.

Presude su analizirane u odnosu na pitanja korištenja zakonskih termina, potpunosti izreka, obrazlaganja odluka o održavanju rasprava u odsutnosti optuženika, forme očitovanja optuženika o optužbama, odluka o troškovima, a posebno u odnosu na kvalitetu obrazlaganja odluka o potrebi $i$ obliku psihijatrijskog liječenja, o čemu te odluke često ne ukazuju jasno na postojanje zakonskih pretpostavki i ne sadrže uvijek dostatne razloge za takve odluke.

Ključne riječi: neubrojivi počinitelji protupravnih radnji, prisilni smještaj u psihijatrijsku ustanovu, psihijatrijsko liječenje na slobodi, obrazlaganje kaznene presude.

* Dražen Tripalo, sudac Vrhovnog suda Republike Hrvatske; drazen.tripalo@vsrh.hr

1 Ovaj rad je sufinancirala Hrvatska zaklada za znanost projektom IP-11-2013-2287 „Legal Status and Real Position of People with Mental Difficulties - Interdisciplinary Approach and European Perspectives" i Sveučilište u Rijeci potporama znanstvenim istraživanjima 13.08.1.3.02 "Interdisciplinarni pristup u istraživanju statusa osoba s duševnim smetnjama kroz prizmu konvencijskog prava". 


\section{1. $U$ VOD}

Zakon o zaštiti osoba s duševnim smetnjama ${ }^{2}$ (dalje: ZZODS) iz 2014. u primjeni je već tri godine, a to je razdoblje dostatno za ocjenu jesu li i u kojoj mjeri ostvareni ciljevi tih zakonodavnih izmjena, pokrenutih nakon uočavanja u praksi brojnih nedostataka ranijega Zakona o zaštiti osoba s duševnim smetnjama ${ }^{3}$ iz 1997. (dalje: ZZODS/97.) koji je stupio na snagu 1. siječnja 1998. godine.

ZZODS/97. donesen je zajedno s Kaznenim zakonom ${ }^{4}$ (dalje: KZ/97.) i Zakonom o kaznenom postupku ${ }^{5}$ (dalje: ZKP/97.), ali je relativno kratko vrijeme nakon toga i u materijalnom i u postupovnom pravu došlo do važnih promjena koje su se odrazile i na položaj neubrojivih počinitelja protupravnih djela, a te će novine u osnovnim crtama biti prikazane u ovome radu.

Radi prikupljanja podataka o primjeni ZZODS-a provedeno je istraživanje postupanja sudova koje je, za proučavanje dobre sudske prakse i uočavanja eventualnih pogrešaka u primjeni tog Zakona i drugih propisa, obuhvatilo dvadeset i pet (25) pravomoćnih sudskih presuda kojima je utvrđeno da su optuženici u neubrojivom stanju počinili protupravna djela te je određeno njihovo psihijatrijsko liječenje - bilo prisilnim smještajem u psihijatrijsku ustanovu, bilo na slobodi. Te su presude izdvojene slučajnim odabirom iz predmeta županijskih sudova kojima su bile dostavljene radi provođenja sudskih odluka o prisilnom smještaju odnosno psihijatrijskom liječenju na slobodi.

Istraživanje je obuhvatilo pravomoćne presude Županijskog suda u Varaždinu (dalje: ŽSVa), Općinskog kaznenog suda u Zagrebu (dalje: OKSZg) te općinskih sudova u Osijeku (dalje: OSOs), Rijeci (dalje: OSRi), Pazinu (dalje: OSPa), Puli Pola (dalje: OSPu), Splitu (dalje: OSSt), Velikoj Gorici (dalje: OSVG), Zlataru (dalje: OSZl) i Novom Zagrebu (dalje: OSNZ) ${ }^{6}$

Od pregledanih 25 presuda, u 17 predmeta određen je prisilni smještaj u psihijatrijsku ustanovu, a u preostalih osam slučajeva određeno je psihijatrijsko liječenje na slobodi. Usprkos slučajnom odabiru predmeta, iznimno je značajan podatak o gotovo četvrtini odluka kojima je određeno psihijatrijsko liječenje na slobodi jer se one odnose na osobe prema kojima bi, po propisima koji su se primjenjivali prije

2 Narodne novine, br. 76/14. - na snazi od 1. siječnja 2015.

3 Narodne novine, br. 11/97., 27/98., 128/99. i 79/02.

4 Narodne novine, br. 110/97., 27/98. - ispravak, 50/00. - Odluka Ustavnog suda Republike Hrvatske, 129/00., 51/01., 111/03., 190/03., 105/04., 84/05., 71/06., 110/07., 152/08., 57/11., 77/11. - Odluka Ustavnog suda Republike Hrvatske - i 143/12.

5 Narodne novine, br. 110/97., 27/98., 58/99., 112/99., 58/02., 143/02. i 115/06.

6 Radi se o presudi ŽSVa broj K-38/15 od 18.12.2015, šest presuda OKSZg broj K-112/16 od 18.2.2016., Kmp-106/15 od 5.10.2015., Ko-1186/15 od 3.11.2015., K-943/15 od 8.9.2015., K-1050/15 od 2.10.2015. i K-268/16 od 8.3.2016., šest presuda OSOs broj K-148/2015 od 26.5.2015., K-227/16 od 22.3.2016., Ksm-58/15 od 19.2.2016., K-744/13 od 8.7.2014., K-289/14 od 10.6.2014., K-469/16 od 9.5.2016., tri presude OSRi K-427/14 od 7.4.2015., K-320/14 od 10.4.2015. i K-532/13 od 18.11.2014., dvije presude OSPa K-171/14 od 5.12.2014. i K-184/14 od 17.12.2014., dvije presude OSPu K-837/15 od 1.9.2015. i K-588/14 od 6.11.2014., dvije presude OSSt K-697/14 od 22.4.2015. i K-952/15 od 20.11.2015., presudi OSVG Kzd-4/15 od 7.9.2015., presudi OSZ1 K-390/14 od 30.3.2016. i presudi OSNZ K-987/15 od 22.12.2015. U nastavku rada one će biti označene naznačenim kraticama imena suda i brojevima predmeta. 
donošenja ZZDOS-a, bio određen prisilni smještaj u psihijatrijske ustanove. Dakle, te osobe bile bi lišene slobode, jednog od najvažnijih među temeljnim ljudskim pravima zajamčenima Ustavom Republike Hrvatske ${ }^{7}$ i europskom Konvencijom za zaštitu ljudskih prava i temeljnih sloboda. ${ }^{8}$

Raščlamba izreka i obrazloženja sudskih odluka obuhvatila je:

- terminologiju korištenu u izrekama presuda u odnosu na pravne oznake protupravnih djela i potpunost tih izreka,

- obrazlaganje (ne)sudjelovanja optuženika na raspravi,

- oblik optuženikovih očitovanja o optužbi,

- obrazlaganje utvrđenja počinjenja protupravnih djela,

- obrazlaganje odluka o prisilnom smještaju ili psihijatrijskom liječenju na slobodi, te

- odluke o troškovima kaznenog postupka.

U analizi je ukazano na uočene propuste u sudskim odlukama koji se odnose na nekorištenje zakonske terminologije, nedostatno obrazlaganje utvrđenja raspravne (ne)sposobnosti neubrojivih optuženika, pogreške pri uzimanju očitovanja optuženika o optužbi, propuste u obrazlaganju počinjenja protupravnih djela, odluke o prisilnom smještaju ili psihijatrijskom liječenju na slobodi te različitu praksu pri donošenju odluka o troškovima kaznenog postupka. Predložene su i mjere radi otklanjanja ovakve nedosljedne prakse i uočenih propusta.

\section{RANIJA REGULATIVA NEUBROJIVIH POČINITELJA PROTUPRAVNIH DJELA}

\subsection{Stanje prije stupanja na snagu ZZODS-a}

Prije donošenja ZZODS/97. zakonska regulativa pravnog statusa osoba s duševnim smetnjama bila je ,parcijalna, neadekvatna, zastarjela i uglavnom se nije primjenjivala. Drugim riječima, zatvaranja i smještaji psihijatrijskih bolesnika u psihijatrijske ustanove poduzimali su se najčešće bez provođenja sudskog postupka i bez donošenja sudske odluke o prisilnoj hospitalizaciji. Na taj način učestalo su se kršile odredbe Ustava RH, ali i brojnih međunarodnih dokumenata koji su štiteći slobodu čovjeka, kao temeljno ljudsko pravo zahtijevali upravo sudsku odluku kao jedini akt kojim se može ograničiti ili oduzeti sloboda. Iako je, dakle, i pravni i stvarni položaj psihijatrijskih bolesnika bio apsolutno neprihvatljiv, nije nezanimljivo primijetiti da donošenje Zakona o zaštiti osoba s duševnim smetnjama nije bilo rezultat takvog neodrživog stanja. Može se pretpostaviti da bi Hrvatska, zbog namjere ulaska u Europsku uniju, vrlo brzo morala donijeti takav ili sličan zakon, međutim neposredni povod donošenju ZZODS bio je novi Kazneni zakon [KZ/97. - op. a.] koji je vezujući krivnju ne samo uz kaznu, već i uz sve kaznenopravne sankcije, isključio

7 Narodne novine, br. 56/90., 135/97., 8/98. - pročišćeni tekst, 113/2000., 124/2000. - pročišćeni tekst, 28/2001., 41/2001. - pročišćeni tekst, 55/2001. - ispravak, 76/2001., 85/2010. - pročišćeni tekst.

8 Narodne novine - Međunarodni ugovori, br. 18/97., 6/99. - pročišćeni tekst. 
mogućnost izricanja sigurnosnih mjera obveznih psihijatrijskih liječenja prema neubrojivim počiniteljima protupravnih radnji."“9

\subsection{Kazneni zakon iz 1997.}

KZ/97. je u članku 40. stavku 1. propisao: „Neubrojiva osoba nije kriva i prema njoj se ne može primijeniti kaznenopravna sankcija." Ovom je odredbom provedeno načelo krivnje iz članka 4. KZ/97., prema kojemu nitko nije mogao biti kažnjen niti se prema njemu mogla primijeniti druga kaznenopravna sankcija (dakle, niti neka od sigurnosnih mjera) ako nije bio kriv za počinjeno djelo. Novelom KZ/97. iz 2000. ${ }^{10}$ stavak 1. članka 40. dopunjen je odredbom da se „neubrojiva osoba može smjestiti u psihijatrijsku ustanovu prema odredbama Zakona o zaštiti osoba sa duševnim smetnjama“, čime je i ovim propisom jasno upućeno na primjenu tog lex specialis prema neubrojivim osobama koje su „ostvarile zakonska obilježja kaznenog djela“ (iako je primjena ZZODS/97. već proizlazila i iz odgovarajućih odredaba tada važećeg ZKP/97. koje su prikazane u nastavku).

\subsection{Zakon o krivičnom postupku i ZKP/97.}

Svi zakoni o kaznenom postupku koji su se primjenjivali u Republici Hrvatskoj od osamostaljenja do danas poznavali su poseban postupak prema okrivljenicima koji su protupravno djelo počinili u stanju neubrojivosti. Stari Zakon o krivičnom postupku ${ }^{11}$ predviđao je poseban postupak za primjenu mjera sigurnosti koji je bio uređen u skladu s tada važećim kaznenim materijalnopravnim modelom izricanja tih „medicinskih“ sankcija okrivljenicima s duševnim smetnjama. ZKP/97. je ovaj postupak prilagodio civilnom modelu inauguriranom ranije spomenutim odredbama članaka 4. i 40. KZ/97. Taj je model kod nas izvorno bio uveden u svom čistom obliku: kazneni sud bio je nadležan utvrđivati počinjenje protupravnog djela i neubrojivost okrivljenika, ali ne i utvrđivati njegovu opasnost i donositi odluku o prisilnom smještaju, za što je bio isključivo nadležan građanski sud u izvanparničnom postupku.

Međutim, način na koji je u nas uveden civilni model uskoro je pokazao brojne nedostatke, pa se opsežnim izmjenama ZKP/97. iZZODS/97. iz 2002. godine pristupilo njegovim izmjenama te je uveden modificirani civilni model, prema kojem je kazneni sud, osim počinjenja protupravnog djela i neubrojivosti njenog počinitelja, nadležan utvrđivati i opasnost okrivljenika. Dakle, do donošenja ZZODS-a i odgovarajućih izmjena ZKP/08. kazneni je sud određivao, ako je utvrdio sve propisane pretpostavke, prisilni smještaj neubrojivom počinitelju protupravnog djela, ali nije bio nadležan odlučivati i o produljenju tog smještaja ili otpustu neubrojive osobe iz psihijatrijske ustanove, što je ostalo u nadležnosti građanskog suda propisanoj odredbama tada važećeg ZZDOS/97. na čiju je primjenu upućivao ZKP/97.

9 Grozdanić, V., Tripalo, D., Novosti u Zakonu o zaštiti osoba s duševnim smetnjama, Hrvatski ljetopis za kazneno pravo i praksu, vol. 20., br. 2., 2013., str. 798.

10 Zakon o izmjenama i dopunama Kaznenog zakona - Narodne novine, br. 129/00.

11 Narodne novine, br. 52/91., 34/93., 38/93. i 28/96. 


\section{AKTUALNA REGULATIVA POLOŽAJA NEUBROJIVIH POČINITELJA PROTUPRAVNIH DJELA}

Razlozi posebnog normiranja postupka prema osobama koje su u stanju neubrojivosti počinile protupravno djelo (koji ne može biti kazneni postupak u užem smislu jer se taj postupak vodi „u slučaju vjerojatnosti da je netko počinio povredu društvenih pravila ponašanja određenu kao kazneno djelo" ${ }^{\text {"12 }}$, a neubrojiva osoba nije kriva pa ne može počiniti „kazneno djelo“ jer je krivnja obilježje kaznenog djela13) mogu se svesti na, s jedne strane, interes društva da se zaštiti od osoba koje su počinile štetna djela, a koja bi, da su počinjena skrivljeno, bila kaznena djela, i to ako postoji opasnost da će te osobe i u budućnosti činiti kaznena djela, a, s druge strane, na zahtjev da se toj osobi zajamče sva prava u postupku koji može rezultirati i njenim lišenjem slobode, dakle, da se taj postupak vodi po standardima kaznenog postupka, ${ }^{14}$ i to uz osiguranje dodatnih jamstava postavljenih radi zaštite specifičnih prava te osobe koja bi inače bila ograničena samim postojanjem njenih duševnih smetnji.

Sadašnja regulativa neubrojivih počinitelja protupravnih djela predstavlja, barem na normativnoj razini, uglavnom usklađeni sustav odredaba novog Kaznenog zakona $^{15}$, ZKP/08. i ZZODS-a. Manje važne nedosljednosti i praznine potrebno je rješavati tumačenjima tih zakona, uz ujednačavanje postupanja sudova i njihove prakse izražene u odlukama koje donose.

\subsection{Novi Kazneni zakon}

KZ/11. je staru formulu načela krivnje iz rimskog prava nulla poena sine culpa doslovno primijenio, ograničivši to načelo samo na isključenje kažnjavanja neubrojivih počinitelja protupravnih djela, ali je izrijekom propisao mogućnost izricanja i neubrojivima nekih sigurnosnih mjera. ${ }^{16},{ }^{17}$ Pritom je u stavku 3. članka

12 Krapac, D. i dr., Kazneno procesno pravo, Prva knjiga: Institucije, Narodne novine, Zagreb, 2010., str. 4.

13 O krivnji kao sastavnom dijelu pojma kaznenog djela te odnosu protupravnosti i krivnje v. Jescheck, H.-H., Weigend, T., Lehrbuch des Strafrechts - Allgemeiner Teil, Duncker \& Humblot, 1996., Berlin, str. 425-427.

14 Naime, nedvojbeno je da su utvrđivanje počinjenja protupravnog djela i neubrojivosti okrivljenika pitanja koja treba rješavati kazneni sud, i to po pravilima koja u najvećoj mogućoj mjeri, s obzirom na pravo okrivljenika na pravični postupak, odgovaraju pravilima kaznenog postupka. Prava okrivljenika iz kaznenog postupka mogu okrivljeniku u ovom postupku biti ograničena samo u mjeri koja je nužna posljedica njegova zdravstvenog stanja, a s druge strane, moraju biti praćena odgovarajućim kompenzatornim mehanizmima.

15 Narodne novine, br. 125/11., 144/12., 56/15. i 61/15. - ispravak; dalje u tekstu: KZ/11.

16 Članak 24. KZ/11.: (1) Neubrojiva osoba nije kriva i ne može joj se izreći kazna. ... (4) Neubrojivoj osobi može se izreći sigurnosna mjera zabrane obavljanja određene dužnosti ili djelatnosti, zabrane upravljanja motornim vozilom, zabrane približavanja, udaljenje iz zajedničkog kućanstva i zabrane pristupa Internetu.

17 Navedena zakonska izmjena na tragu je ideje o „dvotračnosti“ kaznenopravnih sankcija, koja je nastala u pravnoj teoriji njemačkoga pravnog kruga prije Drugog svjetskog rata. V. npr. Roxin, C.: Strafrecht - Allgemeiner Teil, sv. 1., Beck, München, 2006., str. 2. Kritika mogućnosti izricanja sigurnosnih mjera neubrojivima iznesena je u radu Tripalo, D., Burić, 
24. KZ/11. propisao i da će se prema osobi koja je u stanju neubrojivosti ostvarila protupravno djelo postupiti prema odredbama Zakona o zaštiti osoba s duševnim smetnjama.

\subsection{Pretpostavke određivanja prisilnog smještaja i psihijatrijskog liječe- nja na slobodi prema ZZODS-u}

ZZODS je, odgovarajući na zahtjeve deinstitucionalizacije psihijatrijskog liječenja, posebno neubrojivih počinitelja protupravnih djela, uz njihov prisilni smještaj u psihijatrijsku ustanovu uveo i psihijatrijsko liječenje na slobodi koje bi trebalo imati prednost u odnosu na institucijsko liječenje uvijek kada se očekivani rezultati - ponajprije otklanjanje opasnosti takvih osoba - mogu postići i bez njihovog smještaja u psihijatrijsku ustanovu. ${ }^{18}$

ZZODS je u članku 51. odredio kriterije za određivanje tih oblika liječenja osobe za koju sud u kaznenom postupku utvrdi da je počinila protupravno djelo, propisujući da će taj sud odrediti prisilni smještaj te osobe u psihijatrijsku ustanovu u trajanju od šest mjeseci ako je na temelju mišljenja vještaka psihijatra utvrdio da postoji vjerojatnost da bi ona zbog težih duševnih smetnji, zbog kojih je nastupila njezina neubrojivost, mogla ponovno počiniti teže kazneno djelo i da je za otklanjanje te opasnosti potrebno njezino liječenje u psihijatrijskoj ustanovi (stavak 1.), a da će odrediti psihijatrijsko liječenje neubrojive osobe na slobodi u trajanju od šest mjeseci, ako je na temelju mišljenja vještaka psihijatra utvrdio da postoji vjerojatnost da bi ta osoba zbog težih duševnih smetnji, zbog kojih je nastupila njezina neubrojivost, mogla ponovno počiniti teže kazneno djelo i da je za otklanjanje te opasnosti dovoljno njezino liječenje na slobodi. Ova odluka sadrži upozorenje neubrojivoj osobi da će biti prisilno smještena u psihijatrijsku ustanovu ako do dana određenoga rješenjem o upućivanju u psihijatrijsku ustanovu iz članka 53. stavka 4. toga Zakona ne započne liječenje na slobodi.

Dakle, pretpostavka određivanja i prisilnog smještaja neubrojive osobe i njezina psihijatrijskog liječenja na slobodi jest vjerojatnost da bi osoba zbog težih duševnih smetnji, zbog kojih je nastupila njezina neubrojivost, mogla ponovno počiniti teže kazneno djelo, a izbor između ovih oblika ovisi o tome je li za otklanjanje te opasnosti potrebno njezino liječenje u psihijatrijskoj ustanovi ili je za to dovoljno njezino liječenje na slobodi.

Opasnost neubrojivog počinitelja protupravnog djela mora biti posljedica upravo onih težih duševnih smetnji zbog kojih je i nastupila njegova neubrojivost, a ne nekih drugih okolnosti. ${ }^{19}$ Ta se opasnost utvrđuje u kaznenom postupku, i to isključivo na

Z., Položaj neubrojivih počinitelja protupravnih djela u kontekstu novog hrvatskog kaznenog zakonodavstva, Hrvatski ljetopis za kazneno pravo i praksu, vol. 19., br. 2., 2012., str. 511.

18 Više o tome vidi u: Grozdanić, V., Tripalo, D., Novosti u Zakonu o zaštiti osoba s duševnim smetnjama, Hrvatski ljetopis za kazneno pravo i praksu, vol. 20., br. 2, 2013., str. 813. i dalje.

19 Tako ovaj osnovni uvjet za određivanje prisilnog smještaja ili psihijatrijskog liječenja na slobodi neće biti ostvaren ako je počinitelj u stanju neubrojivosti izazvane težim duševnim poremećajem počinio protupravnu radnju ubojstva, a inače je i ovisnik o drogi i zbog te je ovisnosti ranije činio kaznena djela protiv imovine, ako sud na temelju mišljenja vještaka psihijatra utvrdi da 
temelju nalaza i mišljenja vještaka psihijatra. ${ }^{20}$

\subsection{Novi Zakon o kaznenom postupku}

Najvažnije posebnosti postupka prema okrivljenicima kojima je stavljeno na teret počinjenje protupravnog djela u stanju neubrojivosti jesu:

- vođenje postupka samo na zahtjev državnog odvjetnika (članak 549. stavak 2. $\mathrm{ZKP} / 08$.),

- obvezno provođenje istrage (članak 549. stavak 3. ZKP/08.),

- obvezna obrana po branitelju od donošenja rješenja o provođenju istrage (članak 550. stavak 4.),

- posebna osnova za istražni zatvor (koja, u suštini, ima za posljedicu poseban način njegovog izvršavanja - članak 551. stavci 1. i 2. ZKP/08.),

- mogućnost zamjene tog istražnog zatvora posebnom mjerom opreza liječenja na slobodi (članak 551. stavci 3. i 4. ZKP/08.),

- poseban sadržaj optužnice (članak 550. stavak 1. ZKP/08.),

- sudjelovanje u postupku bliskih osoba (članak 552. stavak 1. ZKP/08.)

- obveza ispitivanja optuženika prije rasprave radi ocjene njegove raspravne sposobnosti (članak 552. stavak 3.),

- oblik očitovanja o optužbi (članak 552. stavak 3.),

- sadržaj presude kojom se utvrđuje da je optuženik počinio protupravno djelo, da ga je počinio u stanju neubrojivosti te se određuje prisilni smještaj u psihijatrijsku ustanovu ili psihijatrijsko liječenje na slobodi ${ }^{21}$ u trajanju šest mjeseci uz obvezno određivanje, odnosno produljenje istražnog zatvora (članak 554. stavak 1. ZKP/08.),

- mogućnost tzv. „ekspresne“ optužnice nakon odbijajuće presude donesene zbog nedokazanosti neubrojivosti optuženika (članak 554. stavak 6. ZKP/08.) i

- dostavljanje presude bliskoj osobi (članak 555. stavak 1. ZKP/08.).

- Pojedine odredbe postupovnih i materijalnih propisa bit će izložene u dijelu rada u kojima se analizira njihova primjena u razmatranim sudskim odlukama.

postoji opasnost da će on zbog ovisnosti i dalje činiti kaznena djela protiv imovine, ali da nije vjerojatno da će se ponoviti poremećaj u kojem je počinio navedenu protupravnu radnju.

20 O određenju težih duševnih smetnji i težine djela od čijeg počinjenja postoji opasnost više u: Garašić, J. i dr., Komentar Zakona o zaštiti osoba s duševnim smetnjama, Pravni fakultet, Rijeka, 2015., str. 177. i dalje.

21 Mogućnost određivanja psihijatrijskog liječenja na slobodi uvedena je u ZKP/08. tek Zakonom o izmjenama i dopunama Zakona o kaznenom postupku (Narodne novine, br. 145/13.; dalje: ZIDZKP/13.), a stupanje na snagu odredaba koje se odnose na psihijatrijsko liječenje na slobodi bilo je vezano uz dan stupanja na snagu posebnog zakona kojim se uređuje zaštita osoba $\mathrm{s}$ duševnim smetnjama (članak 261. ZIDZKP/13.), odnosno ZZODS-a. 


\section{ANALIZA SUDSKIH ODLUKA}

\subsection{Terminologija korištena u izrekama presuda u odnosu na pravne oznake protupravnih djela i potpunost tih izreka}

KZ/11. u članku 24. stavku 3. govori o „osobi koja je u stanju neubrojivosti ostvarila protupravno djelo".

U pravnoj teoriji termin „ostvarenja protupravnog djela“ objašnjava se sljedećim razlozima: „Budući da neubrojivost isključuje krivnju, radnja neubrojive osobe mora biti protupravna, tj. ne smije postojati nijedan razlog isključenja protupravnosti. Usmrti li duševni bolesnik drugog u nužnoj obrani, neće se uopće utvrđivati njegova (ne) ubrojivost. Povrh toga, protupravna radnja neubrojivog počinitelja mora sadržavati i sve sastojke krivnje osim ubrojivosti: ako počinitelju kod namjernog kaznenog djela nedostaje namjera, a kod nehajnog kaznenog djela nehaj, opet se neće utvrđivati neubrojivost (osim u slučajevima kada su i namjera i nehaj isključeni zbog nekog od bioloških stanja koja opravdavaju neubrojivost). Stoga je, osim čl. 24. st. 1. u dijelu u kojem je riječ o ostvarenju protupravnog djela, ispravna formulacija i čl. 549. ZKP, prema kojoj se također traži da neubrojivost postoji u vrijeme počinjenja protupravnog djela." ${ }^{22}$

Dakle, terminom „ostvarenje u stanju neubrojivosti protupravnog djela“ zamijenjena je odredba iz KZ/97., koji je govorio o „neubrojivoj osobi koja je ostvarila zakonska obilježja kaznenog djela“ (članak 40. stavak 2.).

Stoga bi, s obzirom na odredbu članka 455. stavka 2. točka 2. u vezi s člankom 549. stavkom 1. ZKP/08. iz koje proizlazi da izreka presude treba sadržavati ,zakonski opis i naziv kaznenog djela i koje su odredbe kaznenog zakona primijenjene“, u izreci „utvrđujuće“ presude iz članka 554. stavka 1. toga Zakona bilo pravilno navesti da je optuženik, primjerice, „u stanju neubrojivosti počinio protupravno djelo protiv osobne slobode - prijetnju - iz članka 139. stavka 3. u vezi s člankom 24. stavkom 2. Kaznenog zakona (,Narodne novine“ broj 125/11., 144/12., 56/15. i 61/15. - ispravak; dalje u tekstu: KZ/11.)“.

Usprkos tome, gotovo sve analizirane odluke u ovome dijelu izreke koriste formulaciju ,čime je u stanju neubrojivosti počinio protupravno djelo zakonskih obilježja kaznenog djela ...", nakon čega se naznačuje glava i naziv kaznenog djela. Samo odluke Općinskog suda u Rijeci ne koriste raniju formulaciju „ostvarenja zakonskih obilježja kaznenog djela“ već se ograničavaju na naznaku „počinjenja protupravnog djela“"(OSRi K-320/14 i K-532/13), ali se samo u jednoj od odluka toga Suda (OSRi K-427/14) navodi da je optuženik ,počinio protupravno kazneno djelo ... u stanju neubrojivosti“.

ZKP/97. je u članku 461. stavku 1. propisivao da će sud, ako je državni odvjetnik postavio zahtjev iz članka 457. stavka 1. toga Zakona, a sud nakon provedene glavne rasprave utvrdi da je optuženik u stanju neubrojivosti počinio protupravno djelo te da postoje uvjeti za određivanje prisilnog smještaja optuženika u psihijatrijsku ustanovu prema odredbama Zakona o zaštiti osoba s duševnim smetnjama, donijeti presudu

22 Novoselec, P., Bojanić, I., Opći dio kaznenog prava, Pravni fakultet, Zagreb, 2013., str. 224. 
kojom se utvrđuje da je optuženik počinio protupravno djelo, da ga je počinio u stanju neubrojivosti te rješenjem odrediti prisilni smještaj u psihijatrijsku ustanovu u trajanju od šest mjeseci.

Međutim, ZKP/08. propisuje da se presudom odlučuje ne samo o utvrđenju optuženikovog počinjenja protupravnog djela u stanju neubrojivosti, nego i o određivanju njegova prisilnog smještaja (sada i psihijatrijskog liječenja na slobodi).

Usprkos tome, u šest pregledanih predmeta sudovi su presudom utvrdili da su optuženici u stanju neubrojivosti počinili protupravno djelo, dok su o njihovu prisilnom smještaju ili psihijatrijskom liječenju na slobodi odlučivali rješenjem (OKSZg, K-112/16 i K-943/15, ŽSVa K-38/15, OSOs K-469/16, OSVG Kzd-4/15 i OSZ1 K-390/14).

Posljednjim rečenicama stavka 1. članka 554. ZKP/08. i stavka 2. članka 51. ZZODS-a propisan je dodatni sadržaj presude kojom je određeno psihijatrijsko liječenje neubrojive osobe na slobodi tako da takva odluka treba sadržavati i upozorenje neubrojivoj osobi da će biti prisilno smještena u psihijatrijsku ustanovu ako do dana određenog rješenjem o upućivanju u psihijatrijsku ustanovu ne započne liječenje na slobodi.

Međutim, od pregledanih osam presuda kojima je određeno psihijatrijsko liječenje optuženika na slobodi dvije (OSSt K-697/14, OSOs K-289/14) ne sadrže takvo upozorenje. Ipak, ovaj propust kaznenog suda ne isključuje mogućnost da sud nadležan prema ZZODS-u postupi u skladu s odredbom članka 55. stavka 3. ZZODS-a i donese rješenje o određivanju prisilnog smještaja neubrojive osobe u psihijatrijsku ustanovu u trajanju od 30 dana.

\subsection{Obrazlaganje (ne)sudjelovanja optuženika na raspravi}

ZKP/08. u članku 552. stavku 2. propisuje obvezu predsjednika vijeća da prije rasprave u prisutnosti vještaka pokuša ispitati optuženika radi ocjene njegove raspravne sposobnosti te da će se, ako sud nakon ispitivanja vještaka utvrdi da je optuženik raspravno nesposoban zbog duševnih smetnji, rasprava održati u optuženikovoj odsutnosti.

U obrazloženjima većine pregledanih presuda opisane su radnje koje je sud proveo radi utvrđenja je li optuženik raspravno sposoban. Pritom u dijelu tih predmeta (OSSt K-697/14, K-952/15, OSPu K-837/15, K-588/14, OSPa K-184/14, OSOs K-744/13) nije naznačeno da je i predsjednik vijeća pokušao ispitati optuženika, već da je (samo) vještak psihijatar pregledao optuženika, a nakon toga dao mišljenje o njegovoj raspravnoj (ne)sposobnosti.

U nekim predmetima (OSRi K-320/14, OSOs Ksm-58/15, OSVG Kzd-4/15) nije obrazlagano postupanje u smislu članka 552. stavka 2. ZKP/08., ali je u svim tim postupcima rasprava provedena u prisutnosti optuženika pa je za pretpostaviti da su sudovi prethodno utvrdili njihovu raspravnu sposobnost.

Međutim, u odluci OSRi K-532/13 rasprava je provedena u odsutnosti optuženika, a u obrazloženju presude ne daju se razlozi zbog kojih optuženik nije bio prisutan raspravi niti se naznačuje je li sud proveo propisani postupak utvrđenja 
raspravne nesposobnosti optuženika.

Iako ZKP/08. ne propisuje izrijekom obvezu suda da u obrazloženju presude naznači razloge održavanja rasprave u odsutnosti optuženika, ta okolnost predstavlja značajnu činjenicu: ako je odluka o održavanju rasprave bez njegove nazočnosti donesena bez prethodno provedenog propisanog postupka, moglo bi se raditi o bitnoj povredi odredaba kaznenog postupka iz članka 468. stavka 1. točke 3. ZKP/08., a u svakom slučaju o onoj iz članka 468. stavka 3. u vezi s člankom 552. stavkom 2. ZKP/08. Stoga bi, radi potpunosti obrazloženja i ukazivanja na pravilnost postupanja, razlozi o takvoj odluci svakako trebali biti sadržani u pisanoj presudi.

Čak i suprotna situacija, provođenje rasprave u prisutnosti optuženika koji je raspravno nesposoban, mogla bi predstavljati relativno bitnu povredu odredaba kaznenog postupka iz članka 468. stavka 2. ZKP/08. Naime, ispitivanjem bi takvog optuženika, koji nije sposoban shvatiti prirodu i svrhu kaznenog postupka, razumjeti pojedine procesne radnje i njihove posljedice, sporazumijevati se $\mathrm{s}$ braniteljem i davati mu upute (članak 325. stavak 5. ZKP/08.), izvjesno došlo do povrede njegovog prava na pravično suđenje. Zbog toga bi i u slučaju utvrđenja raspravne sposobnosti optuženika trebalo u obrazloženju presude ukratko opisati postupak koji je prethodio tom utvrđenju.

\subsection{Oblik optuženikovih očitovanja o optužbi}

Optuženik (prema kojemu se ne vodi postupak prema odredbama glave XXVII.) se u više navrata tijekom postupka ima priliku očitovati optužbi. Iako ZKP/08. ne propisuje striktnu formu tog očitovanja, ono se svodi na dvije mogućnosti: da izjavi da se smatra krivim ili da se ne smatra krivim. Takvo očitovanje značajno je za predmet dokazivanja, redoslijed izvođenja dokaza na raspravi te opseg prava na žalbu odnosno ograničenje žalbenih osnova.

Optuženik kojemu je stavljeno na teret počinjenje protupravnog djela u stanju neubrojivosti ne može biti kriv, pa se od njega ne može niti tražiti neka od navedenih izjava o krivnji. Stoga je člankom 552. stavkom 3. ZKP/08. propisano da će se njegov branitelj (a to se odnosi i na situaciju kada je optuženik prisutan na raspravi) ili on sam, kod očitovanja o optužbi, izjasniti o tome je li (optuženik) počinio protupravno djelo. Ako je optuženik raspravno nesposoban zbog duševnih smetnji pa se rasprava održava u njegovoj odsutnosti, smatrat će se da je porekao osnovanost optužbe (članak 552. stavak 4. ZKP/08.).

Usprkos ovako jasno propisanom sadržaju očitovanja neubrojivog optuženika o optužbi, u velikom broju pregledanih predmeta uočeno je da su sudovi pogrešno konstatirali da su se optuženici očitovali o optužbi na način da su izjavljivali da se „ne smatraju krivima“" (OSSt K-952/15, OSRi K-320/14 i K-532/13, OKSZg K-1050/15) ili da se „smatraju krivima“ (ŽSVa K-38/15, OSOs K-289/14, OSRi K-427/14, OKSZg Kmp-106/15 i K-943/15, OSZ1 K-390/14), a slična je i formulacija da se optuženik „Smatra odgovornim“ (OSOs Ksm-58/15).

Sudovi su (uglavnom) ispravno utvrđivali da se, kada se rasprava održavala u odsutnosti optuženika, „smatra da je porekao osnovanost optužbe“ (OSPu K-837/15 
i K-588/14, OSOs K-148/15, K-227/16 i K-744/13). Međutim, u presudi OSPa K-171/14, donesenoj na raspravi provedenoj u odsutnosti optuženika, nije konstatirano očitovanje optuženika o optužbi, odnosno nije ukazano na ovu zakonsku presumpciju njegova negativnog očitovanja o optužbi.

U dijelu odluka pravilno je konstatirano i očitovanje optuženika o optužbi da „nije počinio protupravno djelo kako mu se stavlja na teret“ (OSNZ K-987/15), odnosno da je ,branitelj okr. ... izjavio da smatra da okr. nije počinio protupravna djela, koja su okr. optužbom stavljena na teret“ (OSOs K-469/16) ili da je „braniteljica okrivljenika ... očitovala se o optužbi na način da je izjavila da optuženik nije počinio protupravno djelo“(OSPa K-184/14), a i pozitivno očitovanje kada je naznačeno da je optuženik izjavio da je „priznao da je djelo počinio“ (OKSZg K-268/16), da „priznaje počinjenje djela koje mu je stavljeno na teret“ (OKSZg Ko-1186/15 i K-112/16) ili „da su istiniti navodi iz optužnice te da su se djela dogodila na način kako je to $\mathrm{i}$ navedeno" (OSVG Kzd-4/15).

\subsection{Obrazlaganje utvrđenja počinjenja protupravnih djela}

Obrazloženja pregledanih presuda donesenih u postupcima u kojima su optuženici porekli počinjenje protupravnih djela, kao i na raspravama provedenima u njihovoj odsutnosti, u dijelu u kojem su se odnosila na činjenična utvrđenja vezana uz samo počinjenje protupravnog djela, nisu odstupala od obrazloženja presuda donesenih u redovnim postupcima, jer su sadržavala uglavnom valjane naznake nespornih činjenica, razloge zbog kojih su sudovi sporne činjenice našli dokazanima ili nedokazanima. Pritom nisu izostale ocjene suda o vjerodostojnosti proturječnih dokaza, razlozi kojima su se vodili pri rješavanju pravnih pitanja, a osobito pri utvrđivanju postojanja obilježja kaznenih djela i primjene određenih odredaba kaznenog zakona na optuženike i njihove radnje (pri čemu su, dakako, umjesto razloga o krivnji optuženika, iznošeni razlozi utvrđenja njihove neubrojivosti). Dakle, ta se obrazloženja uglavnom sačinjena u skladu s odredbama članka 459. (posebno stavka 8.) ZKP/08.

Neka obrazloženja presuda donesenih u postupcima u kojima su (raspravno sposobni) optuženici naveli da priznaju počinjenje protupravnog djela također sadrže razloge činjenica odlučnih za utvrđenje tih djela, dakle, i razloge za utvrđenja onih činjenica koje, zapravo, nisu bile osporene, pri čemu su sudovi ocjenjivali jesu li takva priznanja optuženika potvrđena provedenim dokazima (ŽSVa K-38/15, OSRi K-427/14, OSOs K-289/14, OSZ1 K-390/14, OKSZg K-943/15).

Međutim, u dijelu razmatranih presuda sudovi su, očigledno analogno primjenjujući odredbu članka 459. stavka 7. ZKP/08. (prema kojoj će obrazloženje presude, ako se optuženik o svim točkama optužbe očitovao na način da se smatra krivim, sadržavati samo podatke o kazni), nakon konstatacije optuženikovog priznanja počinjenja protupravnog djela, obrazlagali samo razloge određivanja prisilnog smještaja ili psihijatrijskog liječenja na slobodi (OKSZg Kmp-106/15, K-268/16 i Ko-1186/15, OSVG Kzd-4/15). Takvom postupanju sudova ne može se, načelno, prigovoriti, ali bi se mogle pojaviti dvojbe u drugostupanjskom postupku ako 
bi se očitovanje neubrojivog optuženika da je počinio protupravno djelo izjednačilo s očitovanjem da se smatra krivim. Tada, naime, on ne bi mogao pobijati presudu zbog pogrešno utvrđenog činjeničnog stanja u odnosu na odluku o njegovu prisilnom smještaju ili liječenju na slobodi, osim ako se ta odluka ne bi, u postupovnom smislu, izjednačila s odlukom o kaznenoj sankciji (koja se može pobijati i zbog pogrešno utvrđenog činjeničnog stanja).

\subsection{Obrazlaganje odluka o prisilnom smještaju ili psihijatrijskom liječe- nju na slobodi}

Kazneni sud u pisanoj presudi kojom je prema neubrojivom optuženiku odredio prisilni smještaj ili psihijatrijsko liječenje na slobodi mora obrazložiti dvije pretpostavke za određivanje neke od tih mjera: onu zajedničku, postojanje vjerojatnosti da bi ta osoba zbog težih duševnih smetnji, zbog kojih je nastupila njezina neubrojivost, mogla ponovno počiniti teže kazneno djelo, kao i jednu od posebnih, da je za otklanjanje te opasnosti potrebno njezino liječenje u psihijatrijskoj ustanovi ili da je za to dovoljno njezino liječenje na slobodi.

Obje ove okolnosti utvrđuju se u kaznenom postupku psihijatrijskim vještačenjem (članak 325. stavak 1. ZKP/08.). Nalog kojim se takvo vještačenje određuje trebao bi sadržavati i zadatak vještaku da, ako ocijeni da okrivljenik u vrijeme počinjenja djela nije bio u mogućnosti shvatiti značenje svojeg postupanja ili nije mogao vladati svojom voljom, dade mišljenje o stupnju vjerojatnosti da bi ta osoba zbog duševnih smetnji mogla počiniti teže kazneno djelo i je li za otklanjanje te opasnosti potrebno njeno liječenje u psihijatrijskoj ustanovi ili psihijatrijsko liječenje na slobodi (članak 325. stavak 4. ZKP/08.).

U obrazloženjima pregledanih kaznenih presuda nalazi i mišljenja vještaka psihijatara uglavnom su relativno detaljno reproducirani. Time su, u jednom dijelu presuda, izložena jasna i određena mišljenja vještaka o postojanju navedenih pretpostavki za određivanje neke od ovih mjera kada su se vještaci o njima izrijekom očitovali - bilo odgovarajući na pitanja postavljena im nalogom za vještačenje, bilo pri ispitivanju na raspravi, bilo da su zaključke o njima iznijeli bez posebnih pitanja.

Sud u pravilu prihvaća nalaze i mišljenja vještaka psihijatara ${ }^{23} \mathrm{pa}$, nakon takve ocjene tih dokaza, zaključci vještaka postaju činjenična utvrđenja na temelju kojih se donosi odluka o određivanju prisilnog smještaja ili psihijatrijskog liječenja na slobodi.

Tako je u presudi ŽSVa K-38/15 istaknuto da je vještak psihijatar naveo da: „,.. postoji visoki rizik da bi [optuženik-op.a.] ponovno mogao doći u slično stanje suženja svijesti ... teško je dati dugoročnu procjenu njegovog budućeg stanja. Međutim, zbog visokog rizika od dolaska u slična stanja u budućnosti, a time i rizika od ponavljanja nekog težeg kaznenog djela, potrebno ga je smjestiti u psihijatrijsku ustanovu“. Nakon toga sud ističe da je „vijeće ... zaključilo da ... u budućnosti postoji visoki rizik da bi optuženik mogao doći u stanje sužene svijesti ili psihotičnih simptoma u kojima bi

23 Ni u jednoj od pregledanih presuda nema naznake da bi u ranijem tijeku postupka bilo provedeno psihijatrijsko vještačenje koje sud zbog proturječnosti ili nedostataka ili osnova sumnje u točnost danog mišljenja ne bi prihvatio te da bi bilo određeno novo vještačenje (članak 318 . $\mathrm{ZKP} / 08$.) 
mogao počiniti teže kazneno djelo ... zbog čega su se ispunili uvjeti za određivanje prisilnog smještaja u psihijatrijsku ustanovu prema odredbama Zakona o zaštiti osoba s duševnim smetnjama.“ U presudi OSOs K-148/15 navedeno je da je „na raspravi ... vještak psihijatrijske struke dopunio svoj nalaz i mišljenje te iskazao da postoji visoka razina opasnosti da bi zbog psihičkih poremećaja mogao počiniti teže kazneno djelo te postoji indikacija za smještaj optuženog po čl. 51. Zakona o zaštiti osoba s duševnim smetnjama u odgovarajuću psihijatrijsku ustanovu“. U presudi OSOs Ksm-58/15 istaknuto je da „vještak ... smatra da kod okrivljenog i nadalje postoji vjerojatnost da bi zbog težih duševnih smetnji mogao počiniti teže kazneno djelo, ali je za otklanjanje te opasnosti dostatno psihijatrijsko liječenje na slobodi“, a u presudi OSVG Kzd-4/15 da je vještakinja ,navela da bi okrivljeni zbog težih duševnih smetnji zbog kojih je nastupila njegova neubrojivost mogao ponovno počiniti teže kazneno djelo i da je za otklanjanje te opasnosti potrebno njegovo liječenje u psihijatrijskoj ustanovi sukladno čl. 51. st. 1.“ ZZODS-a. U presudi OSPa K-171/14 navodi se da „stalni sudski vještak... čiji nalaz i mišljenje sud cijeni objektivnim, izrađenim shodno pravilima struke pa ga u cijelosti prihvaća, zaključuje... da... postoji visok stupanj vjerojatnosti i opasnosti da bi razlozi za takvo stanje mogli i u budućnosti poticajno djelovati na okr. za počinjenje novog (pa i težeg) kaznenog djela ${ }^{24}-$ da je potrebno provesti stacionarno liječenje okr. od naznačenog duševnog poremećaja.“ OKSZg u presudi K-1050/15 navodi da „iz nalaza i mišljenja vještaka psihijatra ... proizlazi da opasnost za okolinu na strani okrivljenika još uvijek postoji ali se ona može uspješno otkloniti liječenjem na slobodi ...". U presudi OSNZ K-987/15, nakon citiranja odredbe članka 51. stavka 2. ZZODS-a, navedeno je: „s obzirom na izneseni nalaz i mišljenje liječnika vještaka prema kojemu on kod optuženika nalazi postojanje takve vjerojatnosti te preporučuje sudu primjenu psihijatrijskog liječenja na slobodi, kao dostatne mjere za otklanjanje ove opasnosti, sud je ... optuženiku odredio psihijatrijsko liječenje na slobodi“. Dostatno je kratko obrazloženje u presudi OSSt K-697/14: ,postoji opasnost da optuženik počini teže kazneno djelo te (...) mu je dovoljno odrediti liječenje na slobodi“. U presudi OSOs K-227/16 navodi se da je „,na raspravi ... vještak psihijatrijske struke dopunio svoj nalaz i mišljenje te iskazao da ... postoji opasnost da bi [optuženik - op.a.] i u budućnosti zbog tog duševnog poremećaja mogao počiniti slično ili teže djelo s obilježjima kaznenog djela te je prijedlog da se opt. ... liječi u ustanovi zatvorenog tipa sukladno odredbi čl. 51. Zakona o zaštiti osoba s duševnim smetnjama“. Citirajući nalaz i mišljenje vještaka, OKSZg u presudi Ko-1186/15 ističe da je vještak iskazao da „nema osnova za izricanjem prisilnog smještaja već se njegov lječidbeni program može nastaviti ambulantnim putem s time da bude i dalje pod psihijatrijskom kontrolom ... na taj način bi se osigurao nastavak liječenja ..., a samim tim bi se otklonila mogućnost ponavljanja kaznenih djela, pa i u težem slučaju“. I OSPu u presudi K-837/15 jezgrovito navodi: „temeljem nalaza i mišljenja vještaka utvrđeno je da kod okrivljene egzistira visok

24 Ovakva formulacija o ,poticajnom djelovanju za počinjenje novog kaznenog djela“ prikladnija je utvrđenju pretpostavki za izricanje nekih od sigurnosnih mjera, a za određivanje neke od mjera iz članka 51. ZZODS-a nužno je utvrđenje vjerojatnosti počinjenja kaznenog djela i uzročne veze duševnih smetnji optuženika i takve opasnosti. 
stupanj vjerojatnosti i opasnosti da bi zbog duševnih smetnji mogla počiniti i teže kazneno djelo te da je potrebno provesti stacionarno psihijatrijsko liječenje okrivljene od utvrđenog poremećaja osobnosti““.

Dakle, citirani dijelovi obrazloženja ovih presuda sadrže, manje ili više opsežne, ali svakako određene i jasne razloge utvrđenja navedenih činjenica odlučnih za određivanje prisilnog smještaja ili psihijatrijskog liječenja na slobodi.

Međutim, u nekim nalazima i mišljenjima vještaka psihijatara, kako su oni reproducirani u presudama, nedostaje jasno očitovanje o vjerojatnosti da bi neubrojiva osoba mogla počiniti teže kazneno djelo i/ili o potrebnom obliku liječenja, a ponekad vještaci (iako na to nisu ovlašteni) ,predlažu“ određivanje neke od mjera.

Tako je u presudi OSPu K-588/14 odluka o određivanju prisilnog smještaja obrazložena navodom da „,iz nalaza i mišljenja vještaka proizlazi da postoji visok stupanj opasnosti da bi okrivljena zbog duševne bolesti mogla počiniti novo, pa i teže kazneno djelo, odnosno postoji opasnost od ponavljanja kaznenog djela“, pri čemu se ništa ne navodi o potrebnom obliku liječenja. Također je i u presudi OSOs K-469/16 samo navedeno da je „odlučeno da se u odnosu na okrivljenika odredi prisilni smještaj u psihijatrijsku ustanovu u trajanju od šest mjeseci, a prema odredbama Zakona o zaštiti osoba s duševnim smetnjama, budući je iz nalaza i mišljenja ... vještaka psihijatrijske struke utvrđeno da bi okr. zbog svojih psihotičnih doživljavanja mogao počiniti i teže kazneno djelo, odnosno da je isti opasan za okolinu“. Presudom OSZl K-390/14 odluka o prisilnom smještaju obrazlaže se samo navodom da je „prema mišljenju vještaka [optuženik] potencijalno opasan ${ }^{25}$ za okolinu zbog svoje bolesti i pod utjecajem iste mogao bi počiniti teže kazneno djelo", a takva je odluka u presudi OKSZg K-943/15 obrazložena samo sličnom tvrdnjom da je „vještakinja predložila da se [optuženik] prisilno smjesti u psihijatrijsku ustanovu po čl. 51. u svezi sa čl. 44. st. 2. Zakona o zaštiti osoba s duševnim smetnjama, a upravo s obzirom na potencijalnu opasnost od počinjenja težeg kaznenog djela“.

S druge strane, u presudi OKSZg K-112/16 navedeno je samo da je ,vještakinja svoju odluku pojasnila na način da je navela da za sada nisu ostvareni uvjeti da bi se liječenje moglo provoditi $u$ ambulantnim uvjetima iz razloga što okrivljenik nema uvida i kritičnosti prema svojoj bolesti, on smatra da je duševno zdrav... vještakinja smatra nužnim provesti duže bolničko liječenje na nekom od forenzičkih odjela...". U presudi OKSZg Kmp-106/15 samo se ističe da ,prema navodima dr. ..., [optuženika] treba hospitalizirati na šest mjeseci kako bi se kombiniranom psihoterapijom uz primjenu farmakoterapije postiglo da osuđenik-bolesnik stabilizira svoje stanje, stekne uvid u svoje ponašanje i da ga kontrolira, a za što je nužno i potrebno smještanje u bolnicu ...". Iz citiranog proizlazi da se vještaci u ovim postupcima nisu očitovali o opasnosti optuženika te da sudovi tu opasnost nisu niti utvrdili.

U presudi OSSt K-952/15 navedeno je da je „stalni sudski vještak ... u svom vještačenju naveo kako postoji mogućnost [istaknuo autor] da optuženik, a obzirom na njegovo zdravstveno stanje, počini još teže kazneno djelo, pa je tako predložio

25 Ne ulazeći u obrazlaganje tautologije izraza „potencijalne opasnosti“, ipak treba navesti da ta formulacija sugerira niži stupanj vjerojatnosti ,ponovnog počinjenja kaznenog djela“ koju traže odredbe članka 51. ZZDOS-a. 
[istaknuo autor] kako je tako potrebno provesti obavezno psihijatrijsko liječenje u ustanovi za čuvanje i liječenje [istaknuo autor]“. Ovaj izričaj sugerira primjenu sigurnosne mjere obveznog psihijatrijskog liječenja i čuvanja u zdravstvenoj ustanovi iz članka 50. već dugo nevažećeg Osnovnog krivičnog zakona Republike Hrvatske. ${ }^{26}$

Presudom OSPa K-184/14 određen je prisilni smještaj s obrazloženjem da je „takva odluka sukladna s nalazom i mišljenjem vještaka psihijatra koji je naveo da je neophodno provesti stacionarno (bolničko) liječenje okrivljenika ... od naznačene duševne bolesti“, pri čemu nije obrazloženo niti postojanje vjerojatnosti da će neubrojiva osoba počiniti teže kazneno djelo niti utvrđenje da je za otklanjanje te opasnosti potrebno njezino liječenje u psihijatrijskoj ustanovi.

U presudi OSRi K-532/13 navodi se da ,zbog potpune nekritičnosti optuženika prema svojoj ovisnosti te da je optuženik u etiliziranom stanju opasan po sebe i okolinu vještak smatra neophodnim da se prema optuženiku primijeni sigurnosna mjera obaveznog liječenja od ovisnosti o alkoholu [istaknuo autor] s time da se obavezno liječenje najprije započne u Psihijatrijskoj bolnici ... radi podizanja uvida u bolest, a kasnije (po procjeni liječnika) da se može nastaviti ambulantnim liječenjem. Prihvativši nalaz i mišljenje vještaka psihijatra, sud je optuženiku odredio prisilni smještaj u psihijatrijsku ustanovu prema odredbama Zakona o zaštiti osoba s duševnim smetnjama ...".

OSOs u presudi K-744/13 ističe da je „sud prihvatio nalaz i mišljenje vještaka psihijatra ... i u dijelu u kojem je potvrdio da postoji visoka razina vjerojatnosti da bi okrivljenik u budućnosti mogao počiniti slično ili teže kazneno djelo pod međuutjecajem sniženih mentalnih sposobnosti i alkohola, no, s obzirom isti u svom nalazu nije istaknuo istodobno i da je opasan za okolinu [istaknuo autor], to je sud okrivljeniku ... odredio temeljem čl. 554. st. 1. psihijatrijsko liječenje na slobodi u trajanju od šest mjeseci, a prema odredbama Zakona o zaštiti osoba s duševnim smetnjama." Iz ovakvog obrazloženja proizlazilo bi da za psihijatrijsko liječenje na slobodi nije potrebno utvrditi vjerojatnosti da bi neubrojiva osoba zbog težih duševnih smetnji zbog kojih je nastupila njezina neubrojivost mogla ponovno počiniti teže kazneno djelo, ili pak da niži stupanj te opasnosti (a ne ocjena koje su mjere potrebne za njeno otklanjanje) opravdava određivanje psihijatrijskog liječenja na slobodi umjesto prisilnog smještaja. Sličan stav sugerira i obrazloženje presude OSOs K-289/14 u kojoj je navedeno da je vještak iskazao da je „kroz terapiju unazad tri mjeseca u potpunosti došlo do povlačenja simptoma psihotičnosti, reducirana je opasnost za okolinu [istaknuo autor] te su ispunjeni uvjeti za psihijatrijsko liječenje optuženika na slobodi“, a sud je samo naveo da je, ,, obzirom da je ... utvrdio da je optuženi ... počinio kaznena djela u neubrojivom stanju - ... odlučio da se u odnosu na optuženog ... odredi psihijatrijsko liječenje na slobodi“. Neprimjereno povezivanje stupnja opasnosti s oblikom liječenja proizlazi i iz obrazloženja presude OKSZg K-268/16 u kojoj se ističe da je ,,vještak mišljenja da je obzirom na razinu 'opasnosti za okolinu'... potrebno okrivljenome izreći mjeru obveznog stacionarnog psihijatrijskog liječenja“ pa je prema optuženiku određen prisilni smještaj.

26 "Narodne novine” broj 53/91., 39/92., 91/92., pročišćeni tekst - 31/93., 35/93., 108/95., 16/96. i $28 / 96$. 


\subsection{Odluke o troškovima kaznenog postupka}

Prema općoj odredbi članka 148. stavka 1. ZKP/08. sud će, kad okrivljenika proglasi krivim, u presudi naložiti okrivljeniku da podmiri troškove kaznenog postupka. ${ }^{27}$ Odredba članka 149. stavka 1. ZKP/08. propisuje da će troškovi kaznenog postupka pasti na teret proračunskih sredstava kad se obustavi kazneni postupak ili kada se donese presuda kojom se okrivljenik oslobađa optužbe ili kojom se optužba odbija.

ZKP/08. ne sadrži posebne odredbe o troškovima kaznenog postupka vođenog prema neubrojivom optuženiku. Stoga je otvoreno pitanje ima li mjesta analognoj primjeni odredbe članka 148. stavka 1 . ZKP/08. i u postupcima koji završe presudom kojom se utvrđuje da je optuženik u stanju neubrojivosti počinio protupravno djel, ili bi se tumačenjem iste te odredbe, a contrario, trebalo zaključiti da neubrojivog počinitelja protupravnog djela nije dopušteno obvezati na plaćanje troškova postupka (jer on ne može biti proglašen krivim).

U 17 pregledanih predmeta ova je dvojba bila riješena na način da je neubrojivom optuženiku bilo naloženo platiti troškove kaznenog postupka, i to uglavnom izravnim pozivom na odredbu članka 148. stavka 1 . ZKP/08.

U preostalih osam razmatranih presuda (OKSZg Kmp-106/15, OKSZg Ko1186/15, OKSZg K-112/16, OKSZg K-943/15, OKSZg K-268/16, OSNZ K-987/15, OSVG Kzd-4/15 te OSOs K-469/16 koja je u tom dijelu preinačena presudom Županijskog suda u Zagrebu Kž-534/16 od 8.6.2016., i to po službenoj dužnosti) odlučeno je da troškovi kaznenog postupka padaju na teret proračunskih sredstava.

Prihvatljiva argumentacija iz obrazloženja ovih odluka svodi se na tumačenje da je pretpostavka obvezivanja optuženika na plaćanje troškova presuda kojom je on proglašen krivim za počinjenje kaznenog djela, a da neubrojivi počinitelj protupravnog djela, s obzirom na nepostojanje ubrojivosti kao sastavnice krivnje, ne može biti proglašen krivim.

\section{ZAKLJUČ AK}

Tri godine nakon stupanja na snagu ZZODS-a nužno je razmotriti iskustva u njegovoj primjeni, posebno u odnosu na osobe za koje se u kaznenom postupku utvrđuje da su u stanju neubrojivosti počinile protupravna djela te im se, primjenom upravo odredaba ZZODS-a, određuje prisilni smještaj u psihijatrijsku ustanovu ili psihijatrijsko liječenje na slobodi.

Jedna od najznačajnijih novina koju je uveo ZZODS bila je upravo mogućnost određivanja neubrojivoj osobi, umjesto prisilnog smještaja u psihijatrijsku ustanovu, psihijatrijskog liječenja na slobodi. Činjenica da je u osam od 25 pregledanih presuda

27 Odredba stavka 6. članka 148. ZKP/08. izmijenjena je 2017. i sada propisuje mogućnost oslobođenja od obveze naknade troškova optuženika koji je proglašen krivim, a koji je slabog imovnog stanja. Slična odredba bila je na snazi do prosinca 2013. i sudovi su do tada u pravilu, pozivom na tu odredbu, u nedostatku posebne, oslobađali od obveze naknade troškova postupka neubrojive optuženike. 
neubrojivim osobama određeno upravo liječenje na slobodi jasno upućuje na zaključak o poboljšanju njihovog položaja u kaznenom postupku.

Izložena raščlamba pravomoćnih kaznenih presuda, iako u većini slučajeva sadrže nužne sastojke izreke i obrazloženja, ukazuje na određene neujednačenosti sudske prakse koje su dijelom terminološke naravi (zbog nastavljanja uporabe izraza koji više ne odgovaraju važećim zakonskim terminima), ali većim dijelom i posljedica nedovoljne edukacije kaznenih sudaca o zakonskim novostima u ovoj grani prava. Posebna pozornost u analizi presuda posvećena je kvaliteti obrazlaganja postojanja pretpostavki za određivanje prisilnog smještaja u psihijatrijsku ustanovu ili psihijatrijskog liječenja na slobodi, a ta kvaliteta ne doseže uvijek očekivanu razinu.

Uočeni nedostatci - kako oni koji se odnose na utvrđivanje i obrazlaganje odlučnih činjenica, tako i oni vezani uz različitu sudsku praksu o pojedinim pitanjima - ukazuju na potrebu bolje edukacije svih sudionika ove vrste kaznenih postupaka - ne samo sudaca, nego i državnih odvjetnika, vještaka psihijatara i odvjetnika, a takvo stručno usavršavanje trebaju provoditi odgovarajuće institucije (Pravosudna akademija, Odvjetnička akademija, Hrvatska liječnička komora) u međusobnoj suradnji.

Iskustva u dosadašnjoj primjeni ZZODS-a trebaju biti osnova i za kontinuirani rad na poboljšanju zakonskih tekstova jer zakonske praznine, nejasnoće i proturječja ne trebaju biti samo predmetom tumačenja propisa tijekom njihove primjene, već i povod za angažiranje stručnjaka u rješavanju dvojbi koje, s obzirom na važnost materije, ne smiju biti ostavljene sudskoj praksi čije ujednačavanje, osobito u kaznenoj sferi sudovanja, nije riješeno na odgovarajući način.

\section{LITERATURA}

1. V. Grozdanić, D. Tripalo: Novosti u Zakonu o zaštiti osoba s duševnim smetnjama, Hrvatski ljetopis za kazneno pravo i praksu (Zagreb), vol. 20, broj 2/2013.

2. Krapac, D. i dr., Kazneno procesno pravo, Prva knjiga: Institucije, Narodne novine, 2010. (Zagreb)

3. Tripalo, D., Burić, Z.: Položaj neubrojivih počinitelja protupravnih djela u kontekstu novog hrvatskog kaznenog zakonodavstva, Hrvatski ljetopis za kazneno pravo i praksu (Zagreb), vol. 19, broj 2/2012

4. Garašić, J. i dr.: Komentar Zakona o zaštiti osoba s duševnim smetnjama, 2015. (Rijeka)

5. Jescheck, H.-H., Weigend, T., Lehrbuch des Strafrechts - Allgemeiner Teil, Duncker \& Humblot, 1996. (Berlin)

6. Novoselec, P., Bojanić, I.: Opći dio kaznenog prava, 2013. (Zagreb)

7. Roxin, C.: Strafrecht - Allgemeiner Teil, 2006. (München) 


\title{
Dražen Tripalo*
}

\author{
Summary
}

\section{MENTALLY DISORDERED OFFENDERS OF UNLAWFUL ACTS IN CRIMINAL LAW AND CASE LAW}

This paper presents and analyses legal regulation of the position of mentally incapable perpetrators of unlawful acts from the perspective of criminal law and procedure and the provisions of the Law on Protection of Persons with Mental Disorders, as well as their application in case law, through analysis of 25 final verdicts against mentally incapable persons. The aim of the analysis is to detect good practice, but also questionable and unequal conducts of the courts, in order to improve quality of the decisions and the harmonization of case law. The analysis of the decision encompasses the use of legal terms, completeness of the verdicts, reasoning of the decisions to hold hearings in absence of the defendant, the form of the defendants' statements, the decisions on costs of proceedings and particularly the quality of reasoning on the need of psychiatric treatment.

Keywords: mentally incapable perpetrators, involuntary hospitalization, psychiatric treatment outside the hospital, reasoning of the verdicts.

\section{Zussamenfassung}

\section{SCHULDUNFÄHIGE TÄTER IM STRAFRECHT UND IN DER RICHTERLICHEN RECHTSPRECHUNG DER REPUBLIK KROATIEN}

In der Arbeit wird die Gesetzesregulative hinsichtlich der Lage schuldunfähiger Täter aus der Perspektive des materiellen Strafrechtes und des Strafprozessrechtes sowie auch aus der Perspektive des Gesetzes über den Schutz von Personen mit seelischen Störungen dargestellt. Ebenfalls wird die Anwendung genannter Gesetzesvorschriften in der Rechtsprechung durch die Analyse von 25 rechtskräftigen Strafurteilen gegenüber schuldunfähigen Personen besprochen. Das Ziel dieser Darstellung und Analyse ist es, sowohl Best-Practice-Beispiele richterlicher Rechtsprechung als auch falsche Urteile und die Abweichungen zwischen ihnen festzustellen, um die Qualität der Urteile zu sichern und die Rechtsprechung anzugleichen.

Die Urteile werden hinsichtlich der Anwendung von Gesetzesbegriffen,

* Dražen Tripalo, Judge, Supreme Court of the Republic of Croatia; drazen.tripalo@vsrh.hr 
Vollständigkeit der Rechtsprechung, Begründung der Entscheidungen über Verhandlungen in Abwesenheit des Angeklagten, Form der Ausführung des Angeklagten und der Entscheidungen über Kosten analysiert. Besonderen Wert legt man in der Arbeit der Qualität von Entscheidungen über die Anordnung psychiatrischer Behandlung, weil diese Entscheidungen sehr oft nicht klar auf Gesetzesmerkmale hinweisen und ungenügend begründet sind.

Schlüsselwörter: schuldunfähige Täter, Anordnung der Unterbringung im psychiatrischen Krankenhaus, psychiatrische Behandlung unter Führungsaufsicht, Begründung des Strafurteils.

Riassunto

\section{GLI AUTORI NON IMPUTABILI DI CONDOTTE ILLEGALI NEL DIRITTO PENALE E NELLA GIURISPRUDENZA DELLA REPUBBLICA DI CROAZIA}

Nel lavoro s'illustra la normativa giuridica concernente la posizione degli autori non imputabili di condotte illegali sotto il profilo del diritto penale sostanziale e processuale, come pure della Legge sulla protezione delle persone con disturbi mentali. Viene altresì esaminata l'applicazione di tali norme nella giurisprudenza, mediante l'analisi di 25 sentenze penali passate in giudicato nei confronti di soggetti incapaci di intendere e volere; tutto ciò al fine di individuare sia esempi di buona giurisprudenza, sia casi di errati approcci e di difformità nelle procedure, onde potere elevare il livello della qualità delle sentenze, eliminando le prassi che non sono conformi alle leggi e che impediscono il raggiungimento di un orientamento coeso nella giurisprudenza.

Le sentenze sono state analizzate con riferimento alla questione dell'utilizzo della terminologia giuridica; alla completezza dei dispositivi; alle motivazioni delle decisioni relativamente alla fissazione di dibattimenti in assenza dell'imputato; alla forma di dichiarazione dell'imputato, alle decisioni sulle spese ed in particolare con riferimento alla qualità della motivazione delle decisioni relative alla necessità ed alla forma del trattamento psichiatrico. A tale ultimo riguardo, tali decisioni spesso non indicano chiaramente l'esistenza dei presupposti giuridici e non contengono sempre motivazioni sufficienti per tali decisioni.

Parole chiave: autori non imputabili di condotte illegali; sistemazione coatta in istituto psichiatrico, trattamento psichiatrico in libertà, motivazione della sentenza penale. 
